\section{Differential Large Crabgrass Control with Herbicides in Tall Fescue and Common Bermudagrass}

\author{
B.J. Johnson ${ }^{1}$ \\ Department of Crop and Soil Sciences, Georgia Station, Griffin, GA 30223-1797 \\ Additional index words. Cynodon dactylon, Festuca arundinacea, herbicide residual, \\ oxadiazon, pendimethalin
}

\begin{abstract}
Pendimethalin and oxadiazon are used commonly to control crabgrasses (Digitaria spp.) in tall fescue (Festuca arundinacea Schreb.) and common bermudagrass [Cynodon dactylon (L.) Pers.]. A field experiment was conducted for 2 years to determine if reduced pendimethalin and oxadiazon application rates would control large crabgrass $[D$. sanguinalis (L.) Sco.] effectively in tall fescue and common bermudagrass. Oxadiazon applied at 1.1 $\mathrm{kg}$ a.i./ha in each of two applications at a 60-day interval (less than recommended rate) effectively controlled large crabgrass $(\geq 93 \%)$, regardless of turfgrass species. Pendimethalin applied at $1.1 \mathrm{~kg}$ a.i./ha in each of two applications controlled large crabgrass in common bermudagrass effectively $(\geq 90 \%)$ but not large crabgrass in tall fescue $(47 \%)$. The difference in pendimethalin performance between the two species was attributed to the ability of common bermudagrass to compete more successfully than tall fescue with large crabgrass during late summer. Chemical names used: 3-[2,4-dichloro-5-(1methylethoxy)phenyl]-5-(1,1-dimethylethy1)-1,3,4-oxadiazol-2-(3 H)- one (oxadiazon); $N$ - (1-ethylpropyl)-3,4-dimethyl-2,6-dinitrobenzenamine (pendimethalin).
\end{abstract}

Crabgrasses are a weed problem in most home lawns, athletic fields, golf courses, parks, and other recreation areas. Oxadiazon and pendimethalin are preemergence herbicides used commonly to control crabgrass (Dernoeden and Krouse, 1991; Johnson and Murphy, 1987, 1989, 1993). As the appropriateness of using pesticides on turfgrasses is being questioned, it is desirable to develop ways to reduce the amount of herbicide used.

Some preemergence herbicides have controlled crabgrass acceptably when the full rate was applied the initial year and a reduced rate was applied the second year (Johnson, 1982; Watschke et al., 1980). However, information is limited on whether herbicide application rates can be reduced during the first treatment year.

The response of crabgrass to preemergence herbicides varies among species of cool-season turfgrasses. Pendimethalin applied at $2.8 \mathrm{~kg}$ a.i./ha in Pennsylvania (Watschke and Welterlen, 1982) controls smooth crabgrass [D. ischaemum (Schreb. ex Schweig.) Schreb. ex Muhl] effectively in Kentucky bluegrass (Poa pratensis L.) and creeping red fescue (Festuca rubra L.). However, pendimethalin applied at $1.7 \mathrm{~kg}$ a.i./ha controls smooth and

Received for publication 19 Oct. 1992. Accepted for publication 24 May 1993. Supported by state and Hatch Act funds allocated to the Georgia Agricultural Experiment Stations. I thank J. Davis, station statistician, for his cooperation in these studies and gratefully acknowledge W. Olson, M. Gilmer, and T. Dinkins for technical assistance. The cost of publishing this paper was defrayed in part by the payment of page charges. Under postal regulations, this paper therefore must be hereby marked advertisement solely to indicate this fact. 'Professor. large crabgrass less in Kentucky bluegrass than in perennial ryegrass (Lolium perenne L.) or tall fescue (Festuca arundinacea Schreb.) in New Jersey (Enache and Ilnicki, 1987). Pendimethalin applied at $1.7 \mathrm{~kg}$ a.i./ha in March in Rhode Island (Sawyer and Jagschitz, 1987) controls smooth crabgrass less in creeping red fescue than in Kentucky bluegrass.

In New Jersey, oxadiazon applied at $2.2 \mathrm{~kg}$ a.i./ha controls smooth crabgrass better in perennial ryegrass and tall fescue than in Kentucky bluegrass (Enache and Ilnicki, 1987). In Rhode Island, there is no difference in the level of smooth crabgrass control from oxadiazon applied at $3.4 \mathrm{~kg}$ a.i./ha in creeping red fescue or Kentucky bluegrass (Sawyer and Jagschitz, 1987). Therefore, lower rates of pendimethalin and oxadiazon are associated with greater varion $0=$ no control and $100=$ complete control.

"*Significant at $P \leq 0.01$. ability in crabgrass control among turfgrass species than full rates. There are no data comparisons with pendimethalin or oxadiazon in cool- and warm-season turfgrasses. In the Piedmont region of the southeastern United States, tall fescue is growing actively and common bermudagrass is dormant at the time (February to early March) preemergence herbicides are applied to control large crabgrass. Because large crabgrass germinates while common bermudagrass is dormant or semidormant, it is likely that actively growing tall fescue competes more than common bermudagrass with large crabgrass early growth. Therefore, art experiment was conducted to determine the effects of turfgrass species on large crabgrass control with reduced herbicide application rates.

In Jan. 1991 and 1992 at Griffin, Ga., established tall fescue ('K-3 1') and common bermudagrass stands were overseeded with large crabgrass at $3 \mathrm{~kg} \cdot \mathrm{ha}^{-1}$ and treated with pendimethalin $(60 \mathrm{WDG})$ or oxadiazon $(2 \mathrm{G})$ in one or two applications (Table 1). The full application rate is $3.3 \mathrm{~kg}$ a.i./ha for pendimethalin and $4.5 \mathrm{~kg}$ a.i./ha for oxadiazon. All plots were treated initially on 25 Feb. \pm 1 day, and appropriate plots were treated sequentially on 24 Apr. \pm 2 days. Herbicides were applied initially 2 to 3 weeks before the usual date of large crabgrass germination at Griffin. Pendimethalin was applied as a broadcast spray in 355 liters of water/ha, and granular oxadiazon was applied with a drop spreader. The herbicides were applied to different plots each year.

Tall fescue was fertilized each year with (in kilograms per hectare) $50 \mathrm{~N}-22 \mathrm{P}-42 \mathrm{~K}$ in early September and again in mid-February, and $50 \mathrm{~kg} \mathrm{~N} / \mathrm{ha}$ was applied in November and late May. Common bermudagrass was fertilized each year with (in kilograms per hectare) $50 \mathrm{~N}-22 \mathrm{P}-42 \mathrm{~K}$ in early April and early September, and $50 \mathrm{~kg} \mathrm{~N} / \mathrm{ha}$ was applied mid-May and early July. Actively growing tall fescue was mowed twice a week with a rotary mower to a height of $7 \mathrm{~cm}$ before and after herbicide application. Before herbicide application, dormant common bermudagrass was scalped with

Table 1. Large crabgrass control and turf quality of tall fescue and common bermudagrass at Griffin, $\mathrm{Ga}$., as influenced by rates and frequency of pendimethalin and oxadiazon applications.

\begin{tabular}{|c|c|c|c|c|}
\hline Herbicide $^{2}$ & $\begin{array}{c}\text { Rate } \\
\text { (kg a.i./ha) }\end{array}$ & $\begin{array}{c}\text { Turfgrass } \\
\text { species }\end{array}$ & $\begin{array}{c}\text { Large crabgrass } \\
\text { control }(\%)^{y}\end{array}$ & $\begin{array}{l}\text { Turf quality } \\
(1 \text { to } 10)^{x}\end{array}$ \\
\hline \multirow[t]{6}{*}{ Pendimethalin } & 3.4 & Tall fescue & 53 & 6.8 \\
\hline & & vs. common bermudagrass & $96^{* *}$ & 7.2 \\
\hline & $1.7+1.7$ & Tall fescue & 45 & 6.7 \\
\hline & & vs. common bermudagrass & $91^{* *}$ & 6.8 \\
\hline & $1.1+1.1$ & Tall fescue & 47 & 7.1 \\
\hline & & vs common bermudagrass & $90^{* *}$ & 7.2 \\
\hline \multirow[t]{6}{*}{ Oxadiazon } & 4.5 & Tall fescue & 97 & 7.2 \\
\hline & & vs. common bermudagrass & 97 & 6.9 \\
\hline & $1.1+1.1$ & Tall fescue & 96 & 6.7 \\
\hline & & vs. common bermudagrass & 93 & 7.1 \\
\hline & $0.8+0.8$ & Tall fescue & 76 & 6.7 \\
\hline & & vs. common bermudagrass & 81 & 7.2 \\
\hline
\end{tabular}

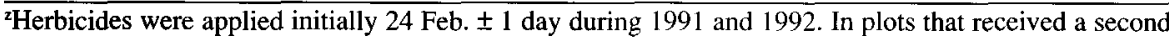
application, the herbicides were applied $23 \mathrm{Apr} . \pm 1$ day.

'Large crabgrass control was rated $27 \mathrm{Aug} . \pm 3$ days and values are averages from 2 years. Ratings were based

${ }^{x}$ Turf quality was rated 27 Aug. \pm 3 days and values are averages from 2 years. Ratings were based on $1=$ turf brown or dead and $10=$ dark green with uniform stand. 
a rotary mower to a height of 1 to $2 \mathrm{~cm}$. After bermudagrass green-up, the turf was mowed three times per week with a reel mower to a height of $3 \mathrm{~cm}$. Clippings were returned to both grasses. Turfgrasses were irrigated as needed to maintain optimum growth. Soil was a Cecil sandy loam (clayey, kaolinitic Thermic Typic Kanhapludult) with a pH of 6.6 and $20 \mathrm{~g} \cdot \mathrm{kg}^{-1}$ organic matter, $67 \%$ sand, $18 \%$ silt, and $15 \%$ clay.

Tall fescue and common bermudagrass quality was rated visually on selected dates from mid-April. until late August. Turfgrass quality ratings were based on a scale of 1 to 10 , where $1=$ turf brown or dead and $10=$ dark green with uniform dense stand. Large crabgrass control was rated in late August and based on crabgrass cover in nontreated plots, where $0 \%=$ no control and $100 \%=$ complete control. Cover for large crabgrass in nontreated plots in late August was $63 \%$ in tall fescue and $67 \%$ in common bermudagrass.

The design was a split plot, with four replications across years. Turfgrass species were the main plots and herbicide treatments were the subplots. Replications were not rerandomized across years; therefore, the data were analyzed using a fixed-effects model. Analysis of variance using SAS's General Linear Model Procedure (SAS Institute, 1982) was conducted within and across years. There was no year $\times$ treatment interaction. Various posthoc contrasts were hypothesized to compare herbicide treatments among turfgrass species.

When oxadiazon was applied sequentially at $1.1+1.1 \mathrm{~kg}$ a.i./ha, large crabgrass control in late August was 93\% in common bermudagrass and $96 \%$ in tall fescue (Table 1). Control from sequential $1.1+1.1 \mathrm{~kg}$ a.i./ha applications was equal to a single oxadiazon application at $4.5 \mathrm{~kg}$ a.i./ha. However, control was less $(\leq 81 \%)$ when oxadiazon was applied twice at $0.8 \mathrm{~kg}$ a.i./ha. The split oxadiazon-oxadiazon application of $1.1+1.1 \mathrm{~kg}$ a.i./ha in the present study resulted in better large crabgrass control than a single $2.2 \mathrm{~kg}$ a.i./ha in common bermudagrass in an earlier study (Johnson and
Murphy, 1993). These results are explained by the long residual of oxadiazon; $75 \%$ remains in the soil 25 weeks after application (Ambrosi et al., 1977).

Large crabgrass control by pendimethalin in late August varied among turfgrass species, regardless of application rate (Table 1). In all instances, pendimethalin controlled large crabgrass $\geq 90 \%$ in common bermudagrass but $<53 \%$ in tall fescue. In contrast to the excellent control in common bermudagrass, poor large crabgrass control with pendimethalin in tall fescue probably was related to different degrees of competition by tall fescue and common bermudagrass during late summer. Tall fescue does not grow well during hot summers (Beard, 1973) and provides minimal competition to the late-season large crabgrass emergence that we observed (data not presented). Nelson et al. (1983) reported that only $15 \%$ of pendimethalin was present in the soil 26 weeks after application. Thus, pendimethalin probably was not persistent during the summer in the present study. Because common bermudagrass is better adapted than tall fescue in the southern United States, the lack of canopy growth of tall fescue, which has an upright growth, allowed late large crabgrass to germinate and emerge. In contrast, common bermudagrass, which is growing actively during the summer and has a better and tighter growth canopy than tall fescue, suppressed large crabgrass germination and emergence.

These results show that caution should be taken in using pendimethalin to control large crabgrass in tall fescue in the Piedmont region of the southeastern United States. However, control was excellent in common bermudagrass. In an earlier study (Johnson, 1982), oxadiazon effectively controlled large crabgrass in common bermudagrass when applied initially at $4.5 \mathrm{~kg}$ a.i./ha, followed by one-half the application rate the following year. Data from the present study showed that the low rate $(1.1 \mathrm{~kg}$ a.i $/ \mathrm{ha})$ of oxadiazon applied twice at a 60 -day interval provided $\geq 90 \%$ control in large crabgrass.

There was no difference in the quality of tall fescue and common bermudagrass treated with pendimethalin or oxadiazon when they were rated in late August (Table 1). Turf quality of nontreated plots (4.9 for tall fescue, 4.3 for common bermudagrass) was lower than that of herbicide-treated turf. The lower quality ratings of nontreated plots was due to large crabgrass competition.

\section{Literature Cited}

Ambrosi, D., P.C. Kearney, and J.A. Macchia. 1977. Persistence and metabolism of oxadiazon in soils. J. Agr. Food Chem. 25:868-872.

Beard, J.B. 1973. Turfgrass: Science and culture. Prentice-Hall, Englewood Cliffs, N.J.

Dernoeden, P.H. and J.M. Krouse. 1991. Selected crabgrass control evaluations for Maryland in 1990. Proc. Northeastern Weed Sci. Soc., Baltimore. 45:117-118.

Enache, A. and R.D. Ilnicki. 1987. Pre and postemergence crabgrass/weed control in turf. Proc. Northeastern Weed Sci. Soc., Williamsburg, Va. 41:215-216.

Johnson, B.J. 1982. Frequency of herbicide treatments for summer and winter weed control in turfgrasses. Weed Sci. 30:116-124.

Johnson, B.J. and T.R. Murphy. 1987. Control of large crabgrass and goosegrass in warm-season turfgrasses. Georgia Agr. Res. Bul. 364.

Johnson, B.J. and T.R. Murphy. 1989. Summer annual weed control in turfgrass. Georgia Agr. Res. Bul. 388.

Johnson, B.J. and T.R. Murphy. 1993. Summer weed control with herbicides in turfgrasses. Georgia Agr. Res. Bul. 411.

Nelson, J.E., W.F. Meggitt, and D. Penner. 1983. Fractionation of residues of pendimethalin, trifluralin, and oryzalin during degradation in soil. Weed Sci. 31:68-75.

SAS Institute. 1982. SAS users guide. SAS Institute, Cary, N.C.

Sawyer, C.D. and J.A. Jagschitz. 1987. Timing of preemergence herbicides for crabgrass control. Proc. Northeastern Weed Sci. Soc., Williamsburg, Va. 41:211-212.

Watschke, T.L. and M.S. Welterlen. 1982. Preemergence crabgrass control in turf. Proc. Northeastern Weed Sci. Soc., New York. 36:298-300.

Watschke, T.L., M.S. Welterlen, and J.M. Duich. 1980. Control of smooth crabgrass in turf using reduced rates the second year. Proc. Northeastern Weed Sci. Soc., Grossinger, N.Y. 34:353-356. 